\title{
La foto del mese
}

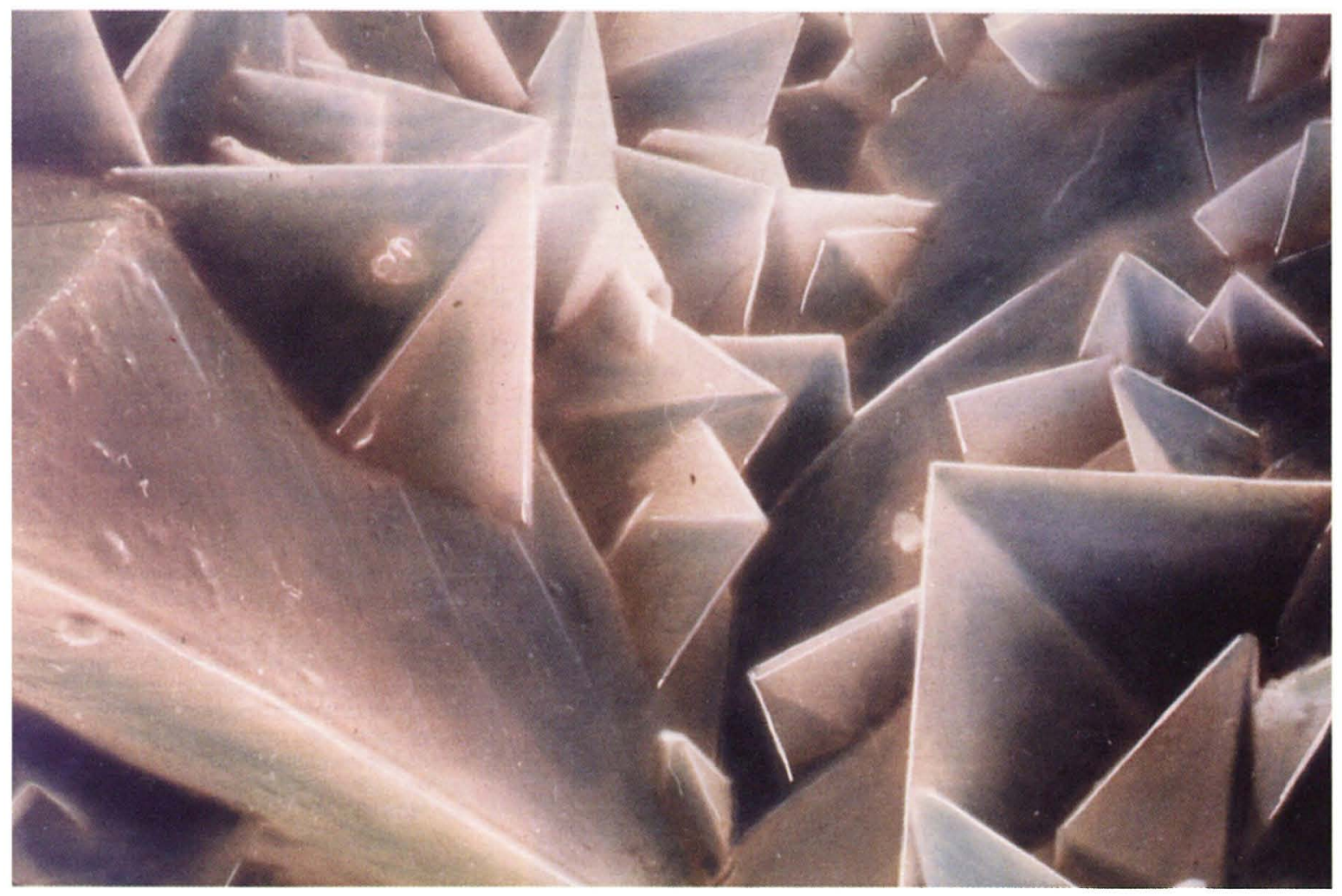

Frammento di calcolo di ossalato di calcio.

Osservazione con microscopio piano e con elaborazione elettronica dell'immagine.

Di Paolo N., Capotondo L., Garosi G.

U.O. Nefrologia - Azienda Ospedaliera Senese

Policlinico Le Scotte - Siena 